\title{
Flexibilization without hesitation? Temporary contracts and job satisfaction
}

\section{By Adrian Chadi ${ }^{\mathrm{a}}$ and Clemens Hetschko ${ }^{\mathrm{b}}$}

\author{
aniversität Trier, Institute for Labour Law and Industrial Relations in the European Union \\ (IAAEU), Behringstraße 21, D-54286 Trier; e-mail: Chadi@iaaeu.de \\ ${ }^{b}$ Freie Universität Berlin, School of Business and Economics, Boltzmannstraße 20, D-14195 Berlin; \\ e-mail: Clemens.Hetschko@fu-berlin.de
}

\begin{abstract}
We use German panel data to examine how fixed-term employment affects utility derived from working. In contrast to previous research, we present evidence that working on a temporary contract lowers current job satisfaction. We discover that the honeymoon effect of a new job must be considered to reveal this result. Job insecurity appears to be the source of dissatisfaction associated with fixed-term employment. We also consider regional unemployment and perceived employment security to shed light on the basic notion of flexicurity policies. Finally, we apply a life course perspective on employment careers to discuss the overall role of temporary employment for individual job satisfaction.
\end{abstract}

\section{Introduction}

During the past decades, many countries have tried to improve the employment prospects of involuntarily unemployed people by mitigating employment protection legislation. The recent economic crisis in Europe has revitalized claims for such flexibilization policies, despite the fact that effects of flexible labour markets on (un-)employment are controversial amongst policy makers and economists (e.g., OECD 2004, 2011). Besides this ongoing debate, research has also started to investigate welfare in the context of employment protection legislation by analysing well-being data (e.g., Becchetti et al., 2010; Ochsen and Welsch, 2012). One policy instrument in this respect is discouraging firms from employing workers on temporary contracts. ${ }^{1}$ Policy makers may hope that the security induced would benefit workers' welfare. Indeed, working on a temporary contract increases job insecurity, that is, worrying about losing one's current job (e.g. Green et al., 2000; Clark and Postel-Vinay, 2009), which is negatively related to well-being (e.g. Sverke et al., 2002; Knabe and Rätzel, 2010, 2011; Lüchinger et al., 2010). Remarkably, previous empirical research on the relationship between

1 Here and in the following, we use the terms 'fixed-term' and 'temporary' synonymously. 
working on a fixed-term contract and job satisfaction does not reveal a clear pattern. Reviews characterize the evidence as 'mixed' (Jahn et al., 2012, p.F116) or 'inconsistent and inconclusive' (de Cuyper et al., 2008, p.26). Numerous articles on this issue show that working under a fixed-term contract has no significant effect on job satisfaction (e.g., Booth et al., 2002; Bardasi and Francesconi, 2004; Wooden and Warren, 2004; Green et al., 2010; Green and Heywood, 2011; de Graaf-Zijl, 2012). ${ }^{2}$ The only exceptions are analyses that do not separately consider inferior forms of employment, which, however, are likely to reflect other negative aspects of work rather than the effect of the fixed-term contract itself.

In the following, we present novel evidence from German panel data and identify job changes as a crucial aspect in this context. When controlling for the 'honeymoon effect' of a new job (e.g., Boswell et al., 2005), our estimations lead to a clearly negative relationship between working under a temporary contract and job satisfaction. The fact that fixed-term workers are more likely than permanent workers to be observed in the particularly happy period right after switching explains why the two groups, at first glance, do not differ regarding job satisfaction. Neglecting the higher prevalence of being new in a job amongst workers on fixed-term contracts might be the reason previous studies could not establish a negative relationship between fixed-term employment and job satisfaction. As our main contribution, we show that taking this aspect into account reveals a negative effect of being on a temporary contract. This finding turns out to be robust to the application of several methodological approaches to analyse differences in job satisfaction.

The significantly negative effect of flexible employment disappears when we control for job security, which according to our analysis of potential channels seems to be the main trigger of dissatisfaction with work amongst temporarily employed people. To provide a comprehensive picture on the role of fixed-term contracts in the labour market and to allow for policy implications, we also shed light on the basic notion of flexicurity. ${ }^{3}$ With respect to potential flexibility-induced utility losses, studies in this context discuss policies enhancing employability as a compensation measure (see, e.g., de Cuyper et al., 2009; Origo and Pagani, 2009; Green, 2011). The underlying idea is that high chances of finding a new job weaken the costs expected from job loss and, hence, reduce worrying about job insecurity induced by labour market flexibility. The results of our sub-group analyses instead point in the opposite direction when employability is measured at the individual level, by perceived employment security or educational attainment. Similarly, we find that certain personality types such as highly conscientious individuals report very negative effects when temporarily employed. The idea of flexicurity receives empirical credence when we turn to an objective indicator for employment security, as fixed-term contracts appear to be less detrimental in times of low unemployment.

2 The inconsistency between theoretical expectation and empirical evidence about the job satisfaction effect of fixed-term employment raises some scepticism concerning subjective evaluations as outcome measures of welfare effects from temporary contracts (Pouliakas and Theodossiou, 2010). Green et al. (2010) find no significant difference in job satisfaction between permanent and fixedterm employees, but conclude that working on a temporary contract lowers work-related welfare when 'objective' job quality is taken into account as well.

3 The concept combines flexbility with security in that it mitigates employment protection legislation but provides substantial public assistance to the unemployed (e.g., van Vliet and Nijboer, 2012). This help can consist of financial support (e.g., generous unemployment benefits) and active labour market policies. The latter is taken up by the European Union, which recommends combining flexible labour markets with measures supporting the employment prospects of job-seekers (e.g., Council of the EU, 2008). 
Finally, we broaden our perspective on fixed-term employment and job satisfaction by applying a long-run analysis, following recent research on well-being over the life cycle (Frijters et al., 2014; Layard et al., 2014). Because of the strong honeymoon effect when starting a new job, temporary employment, which likely fosters job mobility, might be positive overall for workers' job satisfaction in the long run. In fact, the results of our long-run analyses draw a more differentiated picture of fixed-term employment compared with the analysis of someone's current contract type. They conform to the idea that accepting a temporary contract for some time can improve future utility derived from working. For instance, it turns out that previous fixed-term employment is positively related to job satisfaction of mid-career workers when controlling for current fixed-term employment. Thus, against the background of the potentials of flexible employment on the one hand, and its negative effect on current work-related well-being on the other hand, we conclude that policy makers should consider the existing (short-run) drawbacks of temporary employment when establishing the institutional framework. To tackle the problem of reduced job satisfaction of fixed-term workers, measures fighting unemployment appear to be promising.

We proceed as follows. The next section outlines our theoretical expectations and introduces our identification strategy (Section 2). Data and sampling are described in Section 3. Section 4 presents the main results of our study on fixed-term employment, recent job mobility, and current job satisfaction. Afterwards, sub-group analyses address the potential of employability to compensate for insecurity-induced dissatisfaction and provide further sensitivity checks of our findings (Section 5). In Section 6, we present our analysis of the relationship of temporary employment and job satisfaction in the long run. Finally, we conclude and discuss our results (Section 7).

\section{Theoretical considerations and empirical identification}

Perceived job security provided by a permanent contract might benefit satisfaction with work for at least two reasons. First, workers may not fear losing their job, which previous research has identified as an extremely detrimental event (e.g., Clark and Oswald, 1994; Winkelmann and Winkelmann, 1998). Second, they benefit from an option value through the opportunity to stay in the firm, enlarging their set of future employment opportunities, which increases autonomy (e.g., Deci and Ryan, 2000). The lack of job security can also motivate workers to work more unpaid overtime when firms use flexible working contracts to create an incentive scheme and sorting mechanism (e.g., Boockmann and Hagen, 2008; Engellandt and Riphahn, 2005). Working longer hours might thus be another explanation for lower satisfaction amongst fixed-term workers than permanent workers (e.g., Rätzel, 2012). In addition, short tenures are accompanied by weak incentives to invest in good relations with colleagues and superiors, which can also reduce well-being (Gallagher and McLean Parks, 2001). In sum, the utility (U) a worker $i$ derives from an employment relationship with given characteristics (vector $X^{\prime}$ ) is reduced when the contract is temporary (TEMP) instead of permanent, that is,

$$
U_{i}=f_{i}\left(T E M P_{i}, X_{i}^{\prime}\right) ; \text { with } \frac{\partial U_{i}}{\partial T E M P_{i}}<0
$$

The extent to which higher job loss probability, which is associated with a temporary contract rather than with a permanent contract, reduces workers' current utility may depend on the consequences expected from job loss (e.g., Geishecker, 2012). Men, for instance, 
suffer more from unemployment than do women (e.g., Gerlach and Stephan, 1996), which suggests that eq. (1) should be more pronounced amongst men. Moreover, the better workers are able to find a new job with similar job characteristics, the less they need to fear losing their current jobs. Hence, worker characteristics increasing the ability to find a new job (e.g., high education), just like positive macroeconomic trends, should weaken eq. (1). Regarding personality traits, relatively high conscientiousness (Uysal and Pohlmeier, 2011) and low neuroticism (Viinikainen and Kokko, 2012) are likely to improve employability in the case of job loss. The personality of a worker might also play an important role as a determinant of both job satisfaction and selection into flexible forms of employment. Plausibly, certain types of individuals might prefer being on permanent contracts more than others, which suggests controlling for these differences to identify the effect of flexibility. Individuals with more openness to experience, for instance, might be less averse towards temporary contracts.

It is a rather unknown phenomenon amongst labour market economists that being new in a job goes along with extraordinarily high levels of job satisfaction, although only for a short time. In their contribution to the literature on human resource management, Boswell et al. (2005) were the first to find this pattern and named it the 'honeymoon-hangover effect' of a new job. Because fixed-term workers are more likely to be observed at the beginning of a new job than permanent workers, the honeymoon-hangover effect likely influences the empirical relationship between temporary employment and current work-related utility.

Fixed-term employment is characterized by recent and probably also future job mobility, which might yield future honeymoon experiences. Hence, the influence of fixed-term employment on job satisfaction might extend beyond its immediate impact. Some workers' careers may consist of a large number of temporary jobs, whereas others are permanently employed in the same job for almost their whole working life. To learn more about the role of temporary employment, we expand our analysis of the effects from being currently employed in a temporary job by also discussing the role this kind of flexibility plays in employment careers in the long run.

To translate our theoretical considerations into an empirical framework, we approximate $U_{i}$ using job satisfaction $(J S)$ data, that is, $U_{i} \approx J S_{i}$. If eq. (1) holds true, workers might be compensated for working on a temporary contract by earnings and other pleasant features (see also Feldman et al., 1995; Ellingson et al., 1998; Green and Heywood, 2011). Hence, we need to control for earnings and job characteristics when estimating JS. To account for both the extraordinary job satisfaction peak in the first year of a new employment relationship and the decline afterwards (Chadi and Hetschko, 2014), recent mobility (binary variable NEWJOB) and workers' tenure (TENURE in years) are considered.

As we describe in the following section, we can control for an exceptionally large set of job characteristics based on cross-sectional data. This concerns in particular the investigation of relations to colleagues and superiors as channels potentially explaining why fixedterm employment relates to job satisfaction. In contrast, panel data allow us to make use of objective information concerning the insecurity of temporary workers (future termination of employment) as well as to take into account varying levels of regional unemployment. Hence, we make use of both the cross-sectional and the longitudinal data. To account for worker heterogeneity that explains simultaneously being on a fixed-term contract and wellbeing, we control for socio-demographic characteristics $(S D)$ and personality traits $(P)$ 
when performing the cross-section analysis (including the constant $\alpha$ and $\varepsilon_{i}$ as the individual error term):

$$
J S_{i}=\alpha+\beta T E M P_{i}+\gamma X_{i}^{\prime}+\delta N E W J O B_{i}+\phi T E N U R E_{i}+\varphi P_{i}^{\prime}+\eta S D_{i}^{\prime}+\varepsilon_{i}
$$

Our panel estimation takes into account time-variant socio-demographic characteristics as well as time fixed effects $(\tau)$ and individual fixed effects $(\mu)$ :

$$
J S_{i t}=\alpha+\beta T E M P_{i t}+\gamma X_{i t}{ }^{\prime}+\delta N E W J O B_{i t}+\phi T E N U R E_{i t}+\eta S D_{i t}{ }^{\prime}+\tau_{t}+\mu_{i}+\varepsilon_{i t}
$$

Controlling for individual fixed effects is another advantage of the panel approach in comparison with the cross-sectional analysis because personality controls may not account for each time-invariant trait (e.g., ability).

\section{Data}

To analyse the relationship between working on a temporary contract and job satisfaction, we employ cross-section and longitudinal regression analyses using data from the German Socio-Economic Panel study (SOEP, see Wagner et al., 2007). The SOEP is a representative survey of the population of Germany. Each year, several thousand people are interviewed and provide information on their well-being, income, employment status, job characteristics, and more. To ensure the same legal conditions over the whole investigation period, we restrict most of our analyses to the waves from 2001 to 2010. In this period, the German act on part-time and fixed-term work (Teilzeit- und Befristungsgesetz, TzBfG) regulates the use of temporary contracts in Germany. In general, firms are allowed to employ workers on fixed-term contracts for two years ( $\$ 14$ TzBfG 2011). ${ }^{4}$ In addition, employing somebody on a fixed-term contract is possible if the firm can name an objective reason why this is necessary (e.g., the firm needs the worker's service only for a certain time). Hence, successive fixed-term contracts allow firms to employ people temporarily for many years.

A key advantage of using German data for our research purpose is $\$ 4$ of the TzBfG (2011) act. It contributes to the comparability of temporary and permanent employees by prohibiting any kind of discrimination. Both types of workers have to be treated exactly the same with respect to pay and working conditions. The time limit of the contract remains the only systematic difference from the legal point of view. In general, this also applies to employer-employee agreements over dismissal protection during the period of employment (Däubler, 2011). In case such an arrangement does not exist, fixed-term workers are even protected minimally more than permanent workers $(\$ 15,3 \mathrm{TzBfG}, 2011)$.

We identify temporary and permanent employees by a SOEP question on their contract type ('Is your contract of employment for an unlimited or limited period?'). Information about job satisfaction is collected by the question 'Please answer by using the following scale: 0 means "completely dissatisfied", 10 means "completely satisfied". How satisfied are you with your job?' We assume cardinality and translate the answers directly into a variable for the econometric analysis ranging from 0 to 10 . This is in line with previous investigations of well-being on the basis of panel data and relies on the findings of

4 A time limit of four years is possible if the firm is not older than four years. Five years are allowed if the worker has been unemployed for at least four months and is at least 52 years old. 
Ferrer-i-Carbonell and Frijters (2004). ${ }^{5}$ To shed light on the role of job security in the relationship between contract type and job satisfaction, we use the question: 'Are you concerned about your job security?' People answer 'very concerned', 'somewhat concerned', or 'not concerned at all'. A similar question demands a self-assessment of future employment security: 'If you lost your job today, would it be easy, difficult, or almost impossible for you to find a new position which is at least as good as your current one?' As an objective indicator of employment security, we use data from Germany's Federal Statistical Office to calculate regional unemployment rates at the state level.

As explained in the previous section, we employ a cross-sectional and a longitudinal approach. First, we focus on the 2001 SOEP wave, which includes by far the richest set of information on job attributes (e.g., task variety, learning opportunities, and environmental burden). Our longitudinal analysis of data from 2001 to 2010 makes use of information on a smaller set of job characteristics, including basic attributes such as wage, firm size, and sector of industry. We always consider many socio-demographic characteristics, including partnership status, age, sex, and more. The cross-sectional analysis as well as several sub-group tests make use of data on the Big Five personality traits. The Big Five approximate someone's whole personality by assigning values to five traits: extroversion, openness to experience, conscientiousness, neuroticism, and agreeableness (e.g., McCrae and Costa, 1987). They have been ascertained in SOEP surveys for the first time in 2005. We assume that they are stable over time and transfer the measures from 2005 to all of the other waves. ${ }^{6}$ Each trait is measured by three statements. Respondents assess how much the statements apply to themselves on a 7-point scale. The mean of the three answers linked to one trait is the trait's manifestation. Based on these scores, we build binary variables for relatively strong/middle/low manifestations of a trait.

We consider typical German working-age people who are at least 20 years old, but not older than 65 years. To isolate the pure effect of fixed-term work, we exclude inferior jobs such as agency workers, workers who take part in workfare schemes, employees working fewer than 15 hours a week and so-called mini-jobs. As these jobs are always temporary and entail many exceptional attributes, they are not comparable to permanent jobs. We consider the exclusion of such employment forms as an important difference to some of the previous studies (e.g., Booth et al., 2002) and as necessary to reveal the effect of the temporary contract itself. Moreover, we exclude apprentices, self-employed workers, and individuals in other forms of occupational education or retraining. Altogether, we receive a basic sample of 5,769 workers based on the SOEP wave of 2001. Three hundred twenty-eight $(5,441)$ of them work on a temporary contract (permanent contract). The sample for the longitudinal analysis covers 68,286 observations $(4,179$ temporary contracts, 64,107 permanent contracts) from 15,080 respondents.

\section{Fixed-term employment and current job satisfaction}

\subsection{Descriptive findings}

The average job satisfaction of people in our sample who work on temporary contracts does not differ significantly from that of permanent workers (temporary: 7.16,

5 Examining this assumption by employing ordered logit (cross-section) and conditional logit (panel) methods does not yield other qualitative findings to those we present in the following.

6 This assumption relies on research done by Specht et al. (2011) as well as Lucas and Donnellan (2011) indicating that the stability assumption holds for people in the age groups included in our sample. 


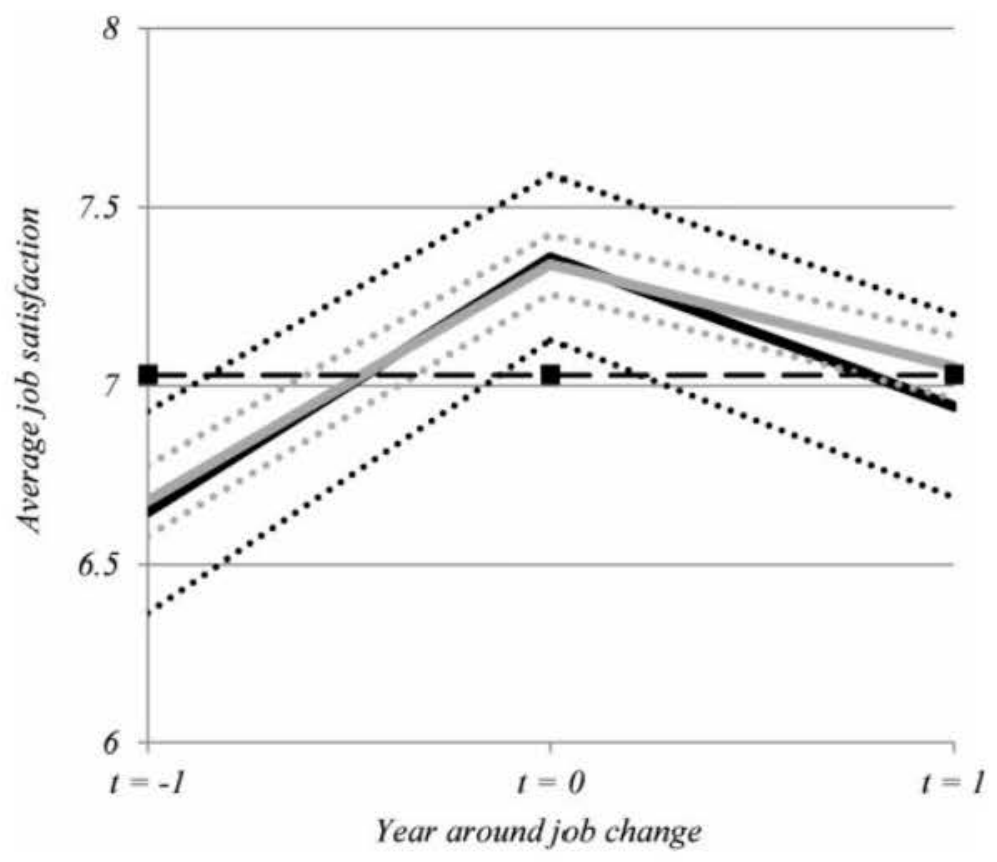

Figure 1. Contract type and the honeymoon-hangover effect of a new job Source: SOEP 2001-2010.

Notes: The solid black line (solid grey line) denotes the average job satisfaction of temporarily (permanently) employed persons in $t=0$ and $t=1$. Dotted lines label the corresponding $95 \%$ confidence intervals. The dashed line denotes the average job satisfaction of all observations in the sample from 2001 to 2010 , with black bars displaying the $95 \%$ confidence band.

permanent: 7.19). This result is in line with previous findings (see Section 1). However, fixed-term employees report significantly lower job security and higher self-assessed employment security compared with permanent workers. Most strikingly, people being on temporary and permanent contracts are different with respect to their tenure and, even more so, with respect to recent job mobility. In fact, more than half of the fixed-term employees report having a new job. These and further descriptive statistics are presented in the Online Appendix, Table A1.

To get an impression of the role job switching plays in our context, we compare the honeymoon-hangover pattern for temporary and permanent workers graphically. As for our large sample, we use all SOEP waves within the investigation period from 2001 to 2010 and apply the same restrictions with respect to age and atypical employment. We follow respondents when they move from one job to another. Around this event, we define three points in time: $t=-1$ as the last SOEP interview in the previous job, $t=0$ as the first, and $t=1$ as the second interview in the new job. The time interval between two interviews is approximately one year.

We compare the average job satisfaction of two groups in Fig. 1. The first group (solid black line) moves from any contract into a temporary one ( 243 observations). The second group (solid grey line) changes from any contract into a permanent one $(1,909$ observations). The type of contract does not change between $t=0$ and $t=1$. The average job satisfaction of all observations in the sample gives a reference level (dashed line), allowing for a graphical illustration of potential honeymoon effects of newly started jobs. In line with the literature (e.g., Clark et al., 1998), individuals report very low levels of job satisfaction 
prior to job termination. Between $t=-1$ and $t=0$, satisfaction with work increases considerably. Overcoming the negative situation of the old job would imply that satisfaction reaches its mean level in $t=0$. Instead, job satisfaction exceeds the average in $t=0$ by far, which points to a honeymoon effect as an above-average satisfaction peak. Afterwards, from $t=0$ to $t=1$, there is a decline in well-being, that is, a potential hangover effect.

Most important for this study is that the two groups show a honeymoon pattern. Accordingly, this phenomenon might bias the difference in job satisfaction between temporary and permanent workers as soon as one of the two groups is observed more often right after switching than at other points in time. Clearly, fixed-term workers appear to be that group.

\subsection{Regression analyses}

In the following, we present our main results of the cross-section investigation and of our panel estimations. We perform ordinary least squares (OLS) estimations of job satisfaction as described by eqs (2) and (3). The results are summarized in Table 1 and reported as a whole in the Online Appendix, Table A2. We specify both models in similar steps (except the respective last step). First (2-1, 3-1), we consider a binary variable for being on a temporary contract. Stable worker characteristics are taken into account as well. The panel estimation considers also time fixed effects. As a result, fixed-term work seems to be unrelated to job satisfaction. Including or excluding the controls considered so far does not alter the temporary contract coefficient substantially. Hence, selection issues because of stable traits seem to be of minor importance in our context. Table A2 reveals further that personality traits relate similarly to job satisfaction as in previous studies (e.g., Judge et al. 2002). ${ }^{7}$

As a second step (2-2, 3-2), we control additionally for socio-demographic characteristics and job characteristics, whereby the cross-sectional analysis makes it possible to control for a more comprehensive set of work attributes. The regression coefficient of the temporary contract variable becomes more negative from $(2-1)$ to $(2-2)$, although the effect remains insignificant. The explanatory power of the model increases notably. Including job attributes as controls causes these changes, whereas socio-demographic characteristics play a minor role. Hence, we find weak evidence that work and firm-related factors compensate workers for accepting a temporary contract.

As a third step $(2-3,2-3)$, we take tenure and tenure squared into account as well as a binary variable for recent change of employment ('new job'). The results show that recent mobility goes along with high job satisfaction. Most important, the effect of being under a temporary contract on job satisfaction turns out to be significantly negative. The panel estimation illustrates a relationship between tenure and satisfaction with work that is U-shaped, as shown by Theodossiou and Zangelidis (2009). The same applies to the crosssection analysis, though it is more pronounced when the binary variable new job is left out. Nevertheless, the combination of this new job dummy with all of the other controls, including tenure and tenure squared, leads to the clearest pattern. The extraordinary magnitude of the first-year effect, which adds to the overall pattern of declining job satisfaction by tenure, justifies our approach of using several variables to control for the honeymoon-hangover effect in

7 As a robustness check, we analyse other traits such as risk aversion (from the 2006 SOEP wave). The results do not change qualitatively when we include alternative control variables for differences in workers' personality. 
Table 1. Regression analyses

\begin{tabular}{|c|c|c|c|c|c|c|c|c|c|c|}
\hline \multirow[b]{2}{*}{ Model specification: } & \multicolumn{5}{|c|}{2001 cross-sectional data } & \multicolumn{5}{|c|}{ 2001-2010 panel data } \\
\hline & $(2-1)$ & $(2-2)$ & $(2-3)$ & $(2-4)$ & $(2-5)$ & $(3-1)$ & $(3-2)$ & $(3-3)$ & $(3-4)$ & $(3-5)$ \\
\hline Temporary contract & $\begin{array}{r}-0.006 \\
(0.115)\end{array}$ & $\begin{array}{r}-0.122 \\
(0.114)\end{array}$ & $\begin{array}{c}-0.235^{* *} \\
(0.117)\end{array}$ & $\begin{array}{r}-0.039 \\
(0.116)\end{array}$ & $\begin{array}{c}0.000 \\
(0.108)\end{array}$ & $\begin{array}{c}0.065 \\
(0.046)\end{array}$ & $\begin{array}{c}0.046 \\
(0.046)\end{array}$ & $\begin{array}{c}-0.121^{* * *} \\
(0.046)\end{array}$ & $\begin{array}{r}-0.008 \\
(0.046)\end{array}$ & \\
\hline$\times$ termination due to contract limit & & & & & & & & & & $\begin{array}{c}-0.396^{* * *} \\
(0.094)\end{array}$ \\
\hline$\times$ no termination due to contract limit & & & & & & & & & & $\begin{array}{c}-0.004 \\
(0.056)\end{array}$ \\
\hline Tenure & & & $\begin{array}{c}-0.017^{*} \\
(0.010)\end{array}$ & $\begin{array}{c}-0.017^{*} \\
(0.009)\end{array}$ & $\begin{array}{c}-0.013 \\
(0.009)\end{array}$ & & & $\begin{array}{c}-0.076^{* * *} \\
(0.007)\end{array}$ & $\begin{array}{l}-0.069^{\text {*** }} \\
(0.007)\end{array}$ & $\begin{array}{c}-0.073^{* * *} \\
(0.008)\end{array}$ \\
\hline Tenure $^{2}$ & & & $\begin{array}{c}0.000 \\
(0.000)\end{array}$ & $\begin{array}{c}0.000 \\
(0.000)\end{array}$ & $\begin{array}{c}0.000 \\
(0.000)\end{array}$ & & & $\begin{array}{l}0.001^{* * *} \\
(0.000)\end{array}$ & $\begin{array}{l}0.001^{\text {क* }} \\
(0.000)\end{array}$ & $\begin{array}{l}0.001^{\text {하 }} \\
(0.000)\end{array}$ \\
\hline New job & & & $\begin{array}{l}0.184^{* *} \\
(0.082)\end{array}$ & $\begin{array}{l}0.198^{* *} \\
(0.080)\end{array}$ & $\begin{array}{c}0.142^{*} \\
(0.076)\end{array}$ & & & $\begin{array}{l}0.243^{\text {*** }} \\
(0.028)\end{array}$ & $\begin{array}{l}0.233^{\text {*n * }} \\
(0.028)\end{array}$ & $\begin{array}{l}0.243^{\text {*** }} \\
(0.032)\end{array}$ \\
\hline Job security: high & & & & $\begin{array}{l}0.485^{* * *} \\
(0.053)\end{array}$ & $\begin{array}{l}0.398^{* * *} \\
(0.050)\end{array}$ & & & & $\begin{array}{l}0.331^{* * *} \\
(0.019)\end{array}$ & \\
\hline Job security: low & & & & $\begin{array}{l}-0.690^{* * *} \\
(0.095)\end{array}$ & $\begin{array}{c}-0.661^{* * *} \\
(0.089)\end{array}$ & & & & $\begin{array}{c}-0.574^{* * *} \\
(0.028)\end{array}$ & \\
\hline Overtime $(\log )$ & & & & & 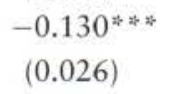 & & & & & \\
\hline Good relations with colleagues & & & & & $\begin{array}{l}0.445^{\text {क幺 स }} \\
(0.064)\end{array}$ & & & & & \\
\hline Bad relations with colleagues & & & & & $\begin{array}{c}0.163 \\
(0.171)\end{array}$ & & & & & \\
\hline
\end{tabular}


Table 1. Continued

\begin{tabular}{|c|c|c|c|c|c|c|c|c|c|c|}
\hline \multirow[b]{2}{*}{ Model specification: } & \multicolumn{5}{|c|}{2001 cross-sectional data } & \multicolumn{5}{|c|}{ 2001-2010 panel data } \\
\hline & $(2-1)$ & $(2-2)$ & $(2-3)$ & $(2-4)$ & $(2-5)$ & $(3-1)$ & $(3-2)$ & $(3-3)$ & $(3-4)$ & $(3-5)$ \\
\hline No conflicts with superiors & & & & & $\begin{array}{l}0.947^{\text {** }} \\
(0.060)\end{array}$ & & & & & \\
\hline Frequent conflicts with superiors & & & & & $\begin{array}{c}-0.943^{* * *} \\
(0.186)\end{array}$ & & & & & \\
\hline Personality & yes & yes & yes & yes & yes & & & & & \\
\hline Individual and time fixed effects & & & & & & yes & yes & yes & yes & yes \\
\hline Socio-demographic characteristics & & yes & yes & yes & yes & & yes & yes & yes & yes \\
\hline Job characteristics (basic) & & yes & yes & yes & yes & & yes & yes & yes & yes \\
\hline Job characteristics, (additional) & & yes & yes & yes & yes & & & & & \\
\hline Constant & $\begin{array}{l}7.180^{\text {** * }} \\
(0.037)\end{array}$ & $\begin{array}{l}6.552^{\text {*** }} \\
(0.205)\end{array}$ & $\begin{array}{l}6.546^{* * *} \\
(0.211)\end{array}$ & $\begin{array}{l}6.453^{\text {*** }} \\
(0.208)\end{array}$ & $\begin{array}{l}5.699^{\text {***4 }} \\
(0.208)\end{array}$ & $\begin{array}{l}7.358^{* * * *} \\
(0.020)\end{array}$ & $\begin{array}{l}7.955^{\text {*** }} \\
(0.478)\end{array}$ & $\begin{array}{l}8.009^{* * *} \\
(0.474)\end{array}$ & $\begin{array}{l}7.932^{* * *} \\
(0.469)\end{array}$ & $\begin{array}{l}7.466^{* * 4} \\
(0.647)\end{array}$ \\
\hline Observations & 5,769 & 5,769 & 5,769 & 5,769 & 5,769 & 68,286 & 68,286 & 68,286 & 68,286 & 54,548 \\
\hline Number of persons & & & & & & 15,080 & 15,080 & 15,080 & 15,080 & 12,851 \\
\hline Adjusted $R^{2}$ & 0.031 & 0.150 & 0.152 & 0.184 & 0.258 & 0.013 & 0.021 & 0.032 & 0.055 & 0.033 \\
\hline
\end{tabular}

Source: SOEP 2001-2010.

Notes: Robust standard errors in parentheses. The dependent variable is job satisfaction. Personality includes openness to experience, conscientiousness, extraversion, agreeableness and neuroticism. Socio-demographic characteristics include gender, age, migration background, single, educational levels, handicap, unemployment experience, and employment experience. Basic job characteristics include firm size, occupational autonomy, industry sector, wage, and working hours. Additional job characteristics include promotion probability, task variety, manual labour, independence in carrying out tasks, performance control, shift work, learning opportunities, annoying tasks, and environmental burden. Complete results are presented in Table A2 in the Online Appendix. "denotes significance at the $10 \%$ level, * at the $5 \%$ level and "* * at the $1 \%$ level. 
our analysis. In addition, variations of the estimations reveal that the new job dummy has the strongest influence on the connection between fixed-term employment and job satisfaction. A specification of eq. (2) including new job as the only control variable leads already to an effect of the temporary contract of around -0.199 (significant at the $10 \%$ level). Since fixedterm workers are observed more often in the exceptionally happy period right after a job change (see Section 4.1), the honeymoon effect increases the estimate of the temporary contract. $^{8}$

Adding self-assessed job security controls to the cross-section and the panel regressions $(2-4,3-4)$ reveals that this factor seems to be the main reason working on a temporary contract relates negatively to job satisfaction. The detrimental effect of the temporary contract almost disappears when controlling for job security. This finding supports our theoretical expectation that the job security added by a permanent contract increases welfare derived from working (see Section 2). In general, job security appears to be a strong determinant of job satisfaction. To investigate the role of further factors that might explain the relationship between working on a temporary contract and job satisfaction, we expand our set of variables by adding overtime as well as relations with colleagues and superiors, which is only possible for the 2001 SOEP data (2-5). The overtime variable is the natural logarithm of the positive differences between actual and agreed-on working hours. Conflicts with superiors and assessments of the relations with colleagues are represented by two binary variables each. The results show that controlling for overtime and internal relations does not strongly alter the temporary contract estimate. Nevertheless, the negative impact of fixed-term work disappears completely as soon as we consider all potential transmission channels discussed in Section 2.

We analyse job security as the explanation for the negative relationship between fixedterm work and satisfaction further by using more objective information. This is in line with research discussing bias issues of estimations regressing subjective outcomes, such as job satisfaction, on subjective evaluations, such as perceived job security (Geishecker, 2012). In so doing, we further improve the identification of the impact of having a fixed-term contract. The panel structure of our data enables us to observe ensuing job terminations taking place because employees reach the end of their contract. We exploit information from the subsequent SOEP interview to divide all observations of temporary jobs in two sub-groups, represented by interaction terms in the panel regression (3-5). The first group of workers' jobs terminate because the contract limit is reached and they are forced out. We consider it plausible that people in this group are likely to experience exogenously induced flexibility. All other fixed-term workers are in the second group. In the next SOEP interview, these workers are either in the same flexible job, or they have changed it, or have lost it due to reasons other than having reached the time limit defined by their contract.

A significantly negative effect of the temporary contract only appears in the case of employees who state in the next interview that the previous employment relationship ended because of contract limitation. Here, the magnitude of the effect is substantially larger compared with the average effect of fixed-term work suggested by (3-3), which is not driven by

8 We confirm our main findings applying matching techniques in the vein of Böckerman and Ilmakunnas (2009) as well as Caliendo and Künn (2011). This removes the linearity assumption of our regressions to some extent and makes fixed-term workers and permanent workers in our 2001 sample more comparable. Methodology and results are described in the Online Appendix (see Caliendo and Kopeinig, 2008, for methodological guidance). 
differences in sample size. We conclude that the use of more objective information strengthens our basic finding. It is the security added by the permanent contract that increases job satisfaction.

Finally, we address whether being employed under a fixed-term contract becomes more acceptable as the share of fixed-term employees increases. Temporary workers might feel more fortunate when conforming to a norm of the labour market than when belonging to an exceptional group. To get an impression, we calculate the share of temporary employees for each of the annual samples from 2001 to 2010 . We do not find convincing evidence that an increasing share of temporary employment weakens the negative link between fixed-term employment and job satisfaction (detailed results are available on request).

\section{Fixed-term employment and job satisfaction across sub-groups of workers}

The previous section suggests a negative relationship of fixed-term employment and job satisfaction as long as we control for recent job mobility. The following sub-group analyses check the sensitivity of this main result. In addition, they enable us to discuss the basic notion of flexicurity. We test the argument that relatively good future employment prospects weaken the expected costs of job loss and, hence, the downside associated with temporary employment suggested before. If true, individuals who perceive their employment prospects to be good in the case of job loss, who face promising macroeconomic trends, or who are highly educated may suffer relatively little from being on a temporary contract. Sample splits address these expectations, for which we use the large panel data set.

First, the sample is divided by workers' assessments of how easy they believe it would be to find a new job in the case of job loss. Those answering 'easy' belong to the 'prospects: good' sub-sample, whilst 'prospects: not good' consists of workers who answer 'difficult' or 'almost impossible'. Estimating specification (3-3) separately for the two groups does not confirm the expectation that high employment security weakens the negative effect of temporary employment (columns (1) and (2) of Table 2). In contrast, the evidence is in line with this expectation when we turn to an objective indicator of employment security in a second step. We split the sample depending on whether the current regional unemployment rate exceeds (i.e., negative macroeconomic trend) or falls below (i.e., positive trend) its long-term average, which we measure for the years from 2001 to 2010. As shown in columns (3) and (4) in Table 2, separate regressions based on these two sub-samples support the view that fixed-term employment is less detrimental when unemployment is relatively low.

Third, we run separate regressions based on sub-samples of workers with and without academic degrees. It turns out that highly educated workers seem to suffer even more from being on a temporary contract than less educated people (columns (5) and (6) in Table 2), which again conflicts with the expectation that high employment security weakens the negative role of flexibility. In sum, our empirical analyses regarding the notion of flexicurity do not yield a clear pattern. To learn more about the role of key socio-demographics in the context of temporary employment, we check the sensitivity of our main results across further sub-groups. Regressions based on gender sub-samples reveal that fixed-term employment appears to be particularly detrimental to male well-being (columns (7) and (8) in 
Table 2. Fixed-term employment effects dependent on employment prospects, gender, and age

\begin{tabular}{|c|c|c|c|c|c|c|c|c|c|c|}
\hline Sub-group & $\begin{array}{l}\text { (1) } \\
\text { Prospects: } \\
\text { good }\end{array}$ & $\begin{array}{l}\text { (2) } \\
\text { Prospects: } \\
\text { not good }\end{array}$ & $\begin{array}{l}\text { (3) } \\
\text { UE rate: } \\
\text { high }\end{array}$ & $\begin{array}{l}\text { (4) } \\
\text { UE rate: } \\
\text { low }\end{array}$ & $\begin{array}{l}\text { (5) } \\
\text { Education: } \\
\text { high }\end{array}$ & $\begin{array}{l}\text { (6) } \\
\text { Education: } \\
\text { not high }\end{array}$ & $\begin{array}{l}\text { (7) } \\
\text { Women }\end{array}$ & $\begin{array}{l}(8) \\
\text { Men }\end{array}$ & $\begin{array}{l}\text { (9) } \\
\text { Up to } 33 \\
\text { years old }\end{array}$ & $\begin{array}{l}(10) \\
\text { Older than } \\
33 \text { years }\end{array}$ \\
\hline Temporary contract & $\begin{array}{r}-0.164 \\
(0.105)\end{array}$ & $\begin{array}{r}-0.089 \\
(0.054)\end{array}$ & $\begin{array}{l}-0.218^{* * *} \\
(0.079)\end{array}$ & $\begin{array}{r}-0.101 \\
(0.069)\end{array}$ & 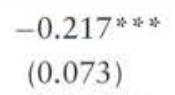 & $\begin{array}{r}-0.083 \\
(0.060)\end{array}$ & $\begin{array}{r}-0.057 \\
(0.065)\end{array}$ & $\begin{array}{l}-0.184^{* \ldots *} \\
(0.065)\end{array}$ & $\begin{array}{c}-0.163^{\text {* * }} \\
(0.078)\end{array}$ & $\begin{array}{c}-0.134^{*} \\
(0.063)\end{array}$ \\
\hline Tenure & $\begin{array}{l}-0.095^{* * *} \\
(0.018)\end{array}$ & $\begin{array}{l}-0.074 \text { ** } \\
(0.007)\end{array}$ & $\begin{array}{c}-0.105^{* * *} \\
(0.013)\end{array}$ & $\begin{array}{l}-0.073^{* * *} \\
(0.009)\end{array}$ & $\begin{array}{c}-0.076^{* * *} \\
(0.011)\end{array}$ & $\begin{array}{c}-0.078^{* * *} \\
(0.009)\end{array}$ & $\begin{array}{c}-0.083^{* * *} \\
(0.011)\end{array}$ & $\begin{array}{c}-0.070 * * \\
(0.008)\end{array}$ & $\begin{array}{l}-0.159^{* * *} \\
(0.026)\end{array}$ & $\begin{array}{c}-0.070^{* * *} \\
(0.007)\end{array}$ \\
\hline Tenure $^{2}$ & $\begin{array}{l}0.002^{* *} \\
(0.001)\end{array}$ & $\begin{array}{l}0.001^{\text {*** }} \\
(0.000)\end{array}$ & $\begin{array}{l}0.002^{* * *} \\
(0.000)\end{array}$ & $\begin{array}{l}0.001^{* * *} \\
(0.000)\end{array}$ & $\begin{array}{l}0.001^{\text {*** }} \\
(0.000)\end{array}$ & $\begin{array}{l}0.001^{* * *} \\
(0.000)\end{array}$ & $\begin{array}{l}0.001^{* * *} \\
(0.000)\end{array}$ & $\begin{array}{l}0.001^{* * * *} \\
(0.000)\end{array}$ & $\begin{array}{c}0.003 \\
(0.002)\end{array}$ & $\begin{array}{l}0.001^{* * *} \\
(0.000)\end{array}$ \\
\hline New job & $\begin{array}{l}0.187^{\text {해 }} \\
(0.068)\end{array}$ & 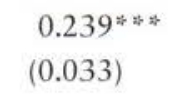 & $\begin{array}{l}0.223^{* * *} \\
(0.044)\end{array}$ & $\begin{array}{l}0.282^{\text {क* }} \text { क } \\
(0.043)\end{array}$ & $\begin{array}{l}0.255^{\text {क年 } \text { क }} \\
(0.044)\end{array}$ & $\begin{array}{l}0.235^{\text {娄类 }} \\
(0.037)\end{array}$ & $\begin{array}{l}0.253^{\text {क苟苟 }} \\
(0.041)\end{array}$ & $\begin{array}{l}0.230^{* 2 * *} \\
(0.039)\end{array}$ & $\begin{array}{l}0.295^{\text {类苟 }} \\
(0.052)\end{array}$ & $\begin{array}{l}0.159 \text { 类 } \\
(0.036)\end{array}$ \\
\hline Controls as (3-3) & yes & yes & yes & yes & yes & yes & yes & yes & yes & yes \\
\hline Constant & $\begin{array}{l}8.896^{\text {** * }} \\
(0.829)\end{array}$ & $\begin{array}{l}7.694^{* * *} \\
(0.584)\end{array}$ & $\begin{array}{l}8.100^{* * *} \\
(0.238)\end{array}$ & $\begin{array}{l}8.002^{* * *} \\
(0.599)\end{array}$ & $\begin{array}{l}8.455^{\text {क* } 4 \text { स }} \\
(0.984)\end{array}$ & $\begin{array}{l}7.840^{* * *} \\
(0.565)\end{array}$ & $\begin{array}{l}8.250 * * * \\
(0.562)\end{array}$ & $\begin{array}{l}7.034^{* \text { * * }} \\
(0.795)\end{array}$ & $\begin{array}{l}7.242^{* * *} \\
(0.550)\end{array}$ & $\begin{array}{l}6.640^{* * *} \\
(0.746)\end{array}$ \\
\hline Observations & 11,436 & 56,850 & 33,524 & 34,762 & 23,795 & 44,491 & 30,657 & 37,629 & 14,622 & 53,664 \\
\hline Number of persons & 5,212 & 13,569 & 11,187 & 12,871 & 5,170 & 10,202 & 7,010 & 8,070 & 5,000 & 11,641 \\
\hline Adjusted $R^{2}$ & 0.036 & 0.031 & 0.027 & 0.033 & 0.033 & 0.033 & 0.032 & 0.034 & 0.047 & 0.031 \\
\hline
\end{tabular}

Source: SOEP 2001-2010.

Notes: Robust standard errors are in parentheses. The dependent variable is job satisfaction. Controls include time and individual fixed effects as well as socio-demographic characteristics and the basic set of job characteristics. They are described in detail in the note of Table 1. A includes only workers who (B: do not) state that it would be easy to find a new job if the current job gets lost. C includes only observations from years in which the regional unemployment rate (federal state level) is (D: not) higher than the average level (measured from 2001 to 2010). E covers only workers with (F: without) academic degree. G consists of women (H: men) only. I considers only workers who are 33 years old or younger (J: older than 33 years). 33 years is the median age of fixed-term employees. Complete results are available on request. "denotes significance at the $10 \%$ level, ${ }^{* *}$ at the $5 \%$ level and $* * *$ at the $1 \%$ level. 
Table 2). This confirms our explanation that psychological costs expected to result from job loss render fixed-term employment negative, as men suffer more from unemployment than women. We also divide the sample into two sub-groups by the median age of fixed-term employees (which is 33 years). The results are very similar for both age groups (columns (9) and (10) in Table 2).

Sample splitting at the median of fixed-term employees is repeated to estimate the effect of temporary employment dependent on personality traits. Hence, we get two sub-groups for each trait (relatively high representation of the trait versus relatively low representation of the trait). The results are summarized in Table 3. A negative relationship of fixed-term employment and job satisfaction appears in particular amongst highly conscientious workers and lowly neurotic workers. Again, our results suggest workers with relatively good prospects when becoming unemployed to suffer the most from being on a temporary contract. A possible explanation is that these workers suffer in particular from unemployment (analogous to men), which previous findings imply for highly educated people (Clark and Oswald, 1994) and highly conscientious people (Boyce et al., 2010). All of the sub-group analyses confirm the positive relationship between recent job mobility and job satisfaction, as we again observe large honeymoon effects. Moreover, we can show that including job security controls always renders the temporary employment effect less negative, suggesting that a higher probability of future unemployment is an important explanation for why fixed-term employment is associated with lower job satisfaction than permanent employment (results are available on request).

\section{Fixed-term employment and job satisfaction from a life course perspective}

Being on a fixed-term contract is accompanied by insecurity and dissatisfaction in the present. However, temporary workers are more likely than permanent workers to experience job changing and thus honeymoon effects in the future, which might compensate for the downsides of flexibility. Furthermore, accepting a fixed-term contract at the beginning of a career might pay off in the future in terms of job security, earnings or promotion (Booth et al., 2002; Engellandt and Riphahn, 2005; Boockmann and Hagen, 2008). These considerations suggest a different picture about the role of temporary employment if we focus on more than just the current situation.

Our panel data allows us to shed some light on work-related well-being over the life cycle. As a first sketch, we go back to our 2001 SOEP sample, for which we have documented negative effects of fixed-term contracts in Section 4, and examine the years afterwards. ${ }^{9}$ Figure 2 shows that the two groups report similar job satisfaction over the years, although on average, satisfaction scores for the temporary workers of 2001 (black lines) appear to be slightly higher when aggregated over the entire period. Moreover, they arrive at a higher job satisfaction level in 2010, compared to those individuals with a permanent contract in 2001 (grey lines).

9 Note that some persons leave our sample of workers for some years or entirely and thus do not contribute to the job satisfaction scores drawn in the figure. The fixed-term employees of the 2001 sample report being unemployed in subsequent years twice as much as permanent employees of the 2001 sample, but in both cases the share is below $10 \%$. All in all, more than half of the temporarily employed of 2001 report job satisfaction in 2010, allowing for a meaningful analysis. 
Table 3. Fixed-term employment effects dependent on personality traits

\begin{tabular}{|c|c|c|c|c|c|c|c|c|c|c|}
\hline Sub-group & $\begin{array}{l}\text { Highly } \\
\text { conscien- } \\
\text { tious }\end{array}$ & $\begin{array}{l}\text { Lowly } \\
\text { conscien- } \\
\text { tious }\end{array}$ & $\begin{array}{l}\text { Highly } \\
\text { agreeable }\end{array}$ & $\begin{array}{l}\text { Lowly } \\
\text { agreeable }\end{array}$ & $\begin{array}{l}\text { Highly } \\
\text { extra- } \\
\text { verted }\end{array}$ & $\begin{array}{l}\text { Lowly } \\
\text { extra- } \\
\text { verted }\end{array}$ & $\begin{array}{l}\text { Highly } \\
\text { open }\end{array}$ & $\begin{array}{l}\text { Lowly } \\
\text { open }\end{array}$ & $\begin{array}{l}\text { Highly } \\
\text { neurotic }\end{array}$ & $\begin{array}{l}\text { Lowly } \\
\text { neurotic }\end{array}$ \\
\hline Tenure & $\begin{array}{l}-0.078^{* * *} \\
(0.009)\end{array}$ & $\begin{array}{l}-0.073^{\text {*** }} \\
(0.010)\end{array}$ & $\begin{array}{l}-0.084^{\text {** }} \\
(0.011)\end{array}$ & $\begin{array}{l}-0.071^{* * *} \\
(0.009)\end{array}$ & $\begin{array}{l}-0.078^{* * *} \\
(0.010)\end{array}$ & $\begin{array}{l}-0.074^{* * *} \\
(0.009)\end{array}$ & $\begin{array}{c}-0.079^{* * *} \\
(0.010)\end{array}$ & $\begin{array}{c}-0.072^{\text {** * }} \\
(0.009)\end{array}$ & $\begin{array}{l}-0.084^{* * *} \\
(0.011)\end{array}$ & $\begin{array}{l}-0.069^{* * *} \\
(0.008)\end{array}$ \\
\hline Tenure $^{2}$ & $\begin{array}{l}0.001 \text { ** } \\
(0.000)\end{array}$ & $\begin{array}{l}0.001^{* * *} \\
(0.000)\end{array}$ & $\begin{array}{l}0.001^{\text {* * }} \\
(0.000)\end{array}$ & $\begin{array}{l}0.001^{* * *} \\
(0.000)\end{array}$ & $\begin{array}{l}0.001 \text { ** * } \\
(0.000)\end{array}$ & $\begin{array}{l}0.001^{\text {*** }} \\
(0.000)\end{array}$ & $\begin{array}{l}0.001^{* * *} \\
(0.000)\end{array}$ & $\begin{array}{l}0.001^{* * *} \\
(0.000)\end{array}$ & $\begin{array}{l}0.001^{* * *} \\
(0.000)\end{array}$ & $\begin{array}{l}0.001^{* * *} \\
(0.000)\end{array}$ \\
\hline New job & $\begin{array}{l}0.242^{\text {* * * }} \\
(0.038)\end{array}$ & $\begin{array}{l}0.248^{\text {하에 }} \\
(0.042)\end{array}$ & $\begin{array}{l}0.208^{\text {*3* }} \\
(0.042)\end{array}$ & $\begin{array}{l}0.266^{* * *} \\
(0.038)\end{array}$ & $\begin{array}{l}0.264^{* \text { * * }} \\
(0.040)\end{array}$ & $\begin{array}{l}0.218^{\text {क* * }} \\
(0.040)\end{array}$ & $\begin{array}{l}0.282^{\text {क* }} \\
(0.041)\end{array}$ & $\begin{array}{l}0.209^{\text {*क * * }} \\
(0.039)\end{array}$ & $\begin{array}{l}0.245^{\text {*क出 }} \\
(0.044)\end{array}$ & $\begin{array}{l}0.237^{* * * *} \\
(0.037)\end{array}$ \\
\hline Controls as (3-3) & yes & yes & yes & yes & Yes & yes & yes & yes & yes & yes \\
\hline Constant & $\begin{array}{l}8.178^{\text {*** }} \\
(0.682)\end{array}$ & $\begin{array}{l}7.843^{* 4 *} \\
(0.651)\end{array}$ & $\begin{array}{l}8.001^{\text {*** }} \\
(0.733)\end{array}$ & $\begin{array}{l}8.090^{* * *} \\
(0.623)\end{array}$ & $\begin{array}{l}8.261 \text { *** } \\
(0.666)\end{array}$ & $\begin{array}{l}7.694^{* * *} \\
(0.673)\end{array}$ & $\begin{array}{l}7.756^{\text {*** }} \\
(0.694)\end{array}$ & $\begin{array}{l}8.103^{* * *} \\
(0.646)\end{array}$ & $\begin{array}{l}7.939^{* * *} \\
(0.706)\end{array}$ & $\begin{array}{l}8.123^{* * *} \\
(0.637)\end{array}$ \\
\hline Observations & 38,640 & 29,646 & 30,336 & 37,950 & 32,561 & 35,725 & 32,564 & 35,722 & 32,345 & 35,941 \\
\hline Number of persons & 9,483 & 5,597 & 8,125 & 6,955 & 8,593 & 6,487 & 8,594 & 6,486 & 8,574 & 6,506 \\
\hline
\end{tabular}

Source: SOEP 2001-2010.

Notes: Robust standard errors are in parentheses. The dependent variable is job satisfaction. Controls include time and individual fixed effects as well as socio-demographic characteristics and the basic set of job characteristics. They are described in detail in the note of Table 1. The sub-groups consist of workers who report either high (above the median of fixed-term employees) or low (up to the median of fixed-term employees) manifestations of the respective trait. Complete results are available on request." denotes significance at the $10 \%$ level, "* at the $5 \%$ level and * * at the $1 \%$ level. 


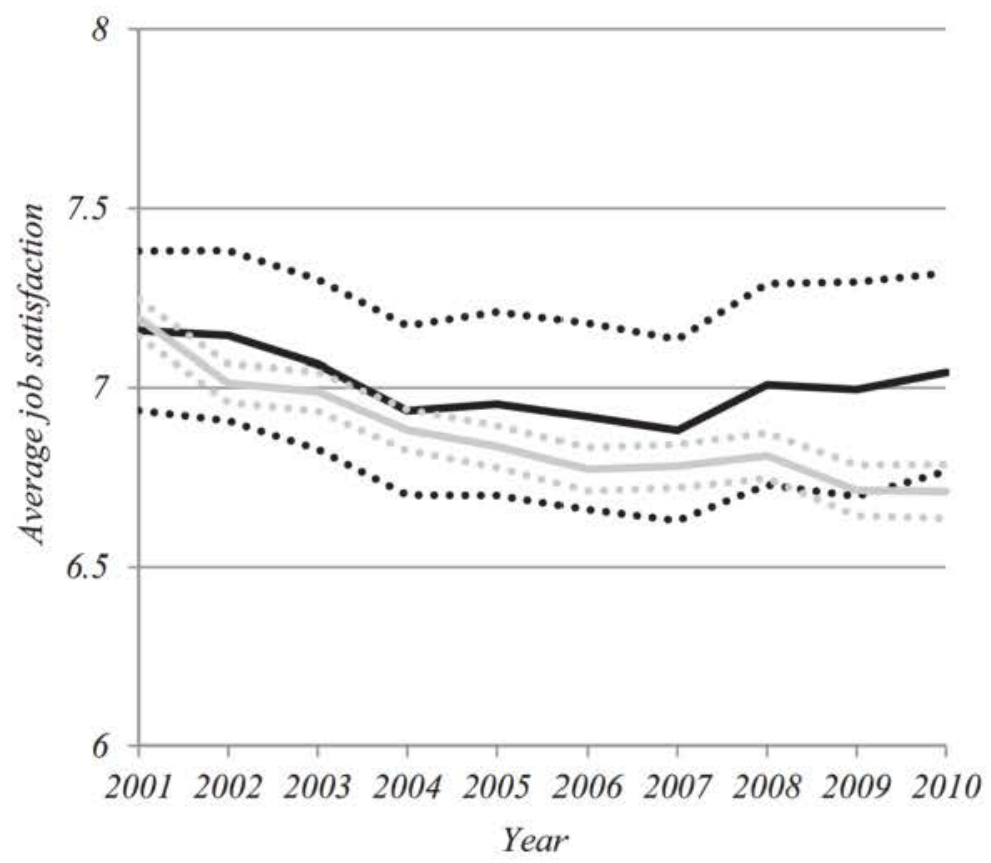

Figure 2. Job satisfaction trajectories after 2001 Source: SOEP 2001-2010.

Notes: Black (grey) lines denote workers starting on a temporary (permanent) contract in 2001. Dashed lines denote $95 \%$ confidence intervals.

Finally, we take a life course perspective on the relationship of fixed-term employment and job satisfaction, inspecting how being on a fixed-term contract at early career stages relates to future work-related utility. This requires that we know how often people have been on a temporary contract or on a permanent contract in the past. We thus identify all young professionals who have not been employed for more than three years prior to being observed in our SOEP data, so that we can reliably count the number of observations of being on a fixed-term contract up to the age of 35 for these persons. Individuals who are not observed since the start of their careers have to be excluded from this analysis, as we cannot identify the number of temporary jobs for those individuals. ${ }^{10}$

Three typical groups emerge: people with no temporary employment experiences, those with one singular observation of temporary employment, and those with more than one reported observation of temporary employment. We find that job satisfaction levels of the three groups do not differ significantly over the entire period from age 25 to age 35. In addition, the job satisfaction means aggregated over these years of age do not vary. Finally, we regress the job satisfaction of mid-career workers (aged 35) on previous temporary employment experience. Controls include time effects, socio-demographic characteristics, and sector of the industry. Results are presented in Table 4. As long as the current contract type is not considered (specifications 1 to 3), observations of fixed-term employment in the past do not seem to matter for current work-related well-being. Controlling for recent job mobility and accumulated lifetime job mobility does not alter

10 Here, we also consider data from the SOEP waves 1995 to 2000 to increase the number of observations. In waves prior to 1995 , it is not possible to clearly distinguish between temporary and permanent jobs. 
Table 4. Early career fixed-term employment and mid-career job satisfaction

\begin{tabular}{|c|c|c|c|c|}
\hline Specification & (1) & (2) & (3) & (4) \\
\hline \multirow{2}{*}{$\begin{array}{l}\text { Observations of fixed-term } \\
\text { employment in the past }\end{array}$} & 0.040 & 0.056 & 0.055 & $0.126^{* * *}$ \\
\hline & $(0.046)$ & $(0.046)$ & $(0.048)$ & $(0.049)$ \\
\hline \multirow[t]{2}{*}{ Observations of 'new job' in the past } & & & -0.054 & -0.063 \\
\hline & & & $(0.046)$ & $(0.046)$ \\
\hline \multirow[t]{2}{*}{ Tenure } & & & -0.022 & -0.052 \\
\hline & & & $(0.059)$ & $(0.060)$ \\
\hline \multirow[t]{2}{*}{ Tenure $^{2}$} & & & 0.002 & 0.003 \\
\hline & & & $(0.003)$ & $(0.003)$ \\
\hline \multirow[t]{2}{*}{ New Job } & & & $0.492^{* *}$ & $0.545^{* *}$ \\
\hline & & & $(0.227)$ & $(0.229)$ \\
\hline \multirow[t]{2}{*}{ Temporary contract } & & & & $-0.895^{* * *}$ \\
\hline & & & & $(0.290)$ \\
\hline Year of the interview & yes & yes & yes & yes \\
\hline Socio-demographic characteristics & yes & yes & yes & yes \\
\hline Sector of the industry & yes & yes & yes & yes \\
\hline \multirow[t]{2}{*}{ Constant } & $7.453^{* * *}$ & $7.806^{* * *}$ & $7.710^{* * 4}$ & $7.969^{* * *}$ \\
\hline & $(0.276)$ & $(0.417)$ & $(0.475)$ & $(0.473)$ \\
\hline Observations & 675 & 675 & 675 & 675 \\
\hline Adjusted $R^{2}$ & 0.006 & 0.014 & 0.019 & 0.032 \\
\hline
\end{tabular}

Source: SOEP 1995-2010.

Notes: Robust standard errors are in parentheses. The dependent variable is job satisfaction. All workers in the sample are 35 years old. Socio-demographic characteristics include gender, migration background, single, educational levels, handicap, unemployment experience, and employment experience. Complete results are available on request. "denotes significance at the $10 \%$ level, * at the $5 \%$ level and ** at the $1 \%$ level.

this finding. However, when controlling for current fixed-term employment, the experience of previous fixed-term employment turns out to be positively related to current job satisfaction (specification 4). Hence, one explanation why early-career temporary employment does not constitute a positive factor in mid-career well-being might be that it is associated with current temporary employment. In the absence of temporary employment at mid-career stages, the picture of temporary contracts in the past obviously becomes more positive.

\section{Conclusion and discussion}

Previous research suggests job security to be one of the most important requirements for work-related well-being. Studies also show that fixed-term employment reduces job security. Nevertheless, whilst numerous analyses have investigated the effects of flexible employment contracts on job satisfaction, they could not identify clear patterns (De Cuyper et al., 2008). We aim at reconciling these contradictory findings using representative German panel data. In contrast to previous research, we explicitly account for the extraordinary new job effect that turns out to be highly relevant for the relationship between fixed-term work and job satisfaction. The fact that temporary employees are more likely than permanent employees to have switched jobs recently explains why both groups report similar 
levels of job satisfaction on average. Our study suggests that the neglect of this phenomenon is responsible for the inconclusive evidence provided so far. Likewise, researchers who analyse job satisfaction as an outcome or as a predictor of behaviour should be aware of the honeymoon-hangover pattern. ${ }^{11}$

We identify job insecurity as the main channel for fixed-term employment's reduction of current workers' well-being. Strong negative effects are found for those individuals who suffer objectively from insecurity when they are about to lose their jobs because of reaching the time limit of the contract. With our analysis, we provide one argument of many that need to be considered in a comprehensive cost-benefit analysis of labour market flexibilization that would, for example, also take into account implications for unemployed individuals (see e.g. de Graaf-Zijl et al., 2011).

A honeymoon experience at the beginning of a new employment relationship might also be an advantage of fixed-term employment, which the analysis of current job satisfaction neglects. In fact, the life course patterns we describe suggest no negative relationship between temporary employment and job satisfaction in the future. Temporary employment spells even seem to benefit the well-being of mid-career workers as long as they are not employed temporarily in the present. This is in line with Booth et al. (2002), who find that temporary employment can be a stepping stone for future career success. However, temporary employment in the past increases the probability of being fixed-term employed in the present, which is why bygone fixed-term employment spells do not appear to pay off in general.

In sum, our study provides several policy-relevant insights to address the question raised in its title. Fixed-term employment can, on the one hand, influence individual welfare derived from working negatively, as the lack of job security appears to be detrimental. On the other hand, there are potential benefits of temporary employment in form of promising changes when one finds a new job and long-run advantages in the course of an employment career. The resulting policy challenge is, hence, how the negative consequences of currently being on a fixed-term contract can be reduced. Flexicurity principles suggest measures improving employability. Interestingly, sub-groups of workers who do not need to fear long unemployment durations in the case of job loss (i.e., individuals with high perceived employment security, high educational attainments, low neuroticism, high conscientiousness) tend to suffer in particular from being on a fixed-term contract. Perhaps they expect relatively high costs of job loss, for instance, because they benefit from relatively pleasant job characteristics and relatively high earnings when employed. We also find that fixedterm employment is less detrimental when regional unemployment is relatively low. Thus, our study suggests combining flexible labour markets (that allow firms to employ workers on temporary contracts) with policies to reduce aggregate unemployment. If labour market flexibilization succeeds in reducing overall unemployment by itself, this might already provide some of the compensation required to make fixed-term workers as happy with their working lives as permanent workers are.

11 The validation of Boswell et al.'s (2005) findings from data of US high-level managers demands a deeper analysis of generalizability and causality of the new job effect, which we provide in Chadi and Hetschko (2014). 


\section{Acknowledgements}

The authors are grateful for comments by Andreas Knabe, Marco Caliendo, Andrew Clark, Laszlo Goerke, Steffen Künn, Ronnie Schöb, and Tobias Wolf as well as participants of the FU Berlin Research Seminar in Economics, the Research Seminar of the Berlin Network of Labor Market Research, the Potsdam Workshop in Empirical Economics, the 10th International SOEP User Conference (Berlin 2012), the 11th TIBER Conference (Tilburg 2012), the 11th Workshop on Public Economics (Berlin 2012), the 3rd SEEK Conference (Mannheim 2013), the Beyond Wages Workshop (London 2013), the Statistical Week (Berlin 2013), the 25th EALE Conference (Turin 2013), and the 10th TEPP Conference (Le Mans 2013). We also thank two anonymous referees for very helpful suggestions.

\section{References}

Bardasi, E. and Francesconi, M. (2004) The impact of atypical employment on individual wellbeing: evidence from a panel of British workers, Social Science and Medicine, 58, 1671-88.

Becchetti, L., Castriota, S. and Giuntella, G.O. (2010) The effects of age and job protection on the welfare costs of inflation and unemployment, European Journal of Political Economy, 26, $137-46$.

Böckerman, P. and Ilmakunnas, P. (2009) Unemployment and self-assessed health: evidence from Panel Data, Health Economics, 18, 161-79.

Boockmann, B. and Hagen, T. (2008) Fixed-term contracts as sorting mechanisms: evidence from job durations in West Germany, Labour Economics, 15, 984-1005.

Booth, A.L., Francesconi, M. and Frank, J. (2002) Temporary jobs: stepping stones or dead ends?, Economic Journal, 112, F189-F213.

Boswell, W.R., Boudreau, J.W., and Tichy, J. (2005) The relationship between job change and job satisfaction: the honeymoon-hangover-effect, Journal of Applied Psychology, 90, 882-92.

Boyce, C.J., Wood, A.M. and Brown, G.D.A. (2010) The dark side of conscientiousness: conscientious people experience greater drops in life satisfaction following unemployment, Journal of Research in Personality, 44, 535-9.

Caliendo, M. and Kopeinig, S. (2008) Some practical guidance for the implementation of propensity score matching, Journal of Economic Surveys, 22, 31-72.

Caliendo, M. and Künn, S. (2011) Start-up subsidies for the unemployed: long-term evidence and effect heterogeneity, Journal of Public Economics, 95, 311-31.

Chadi, A. and Hetschko, C. (2014) The magic of the new: how job changes affect job satisfaction, IAAEU Discussion Paper 5/2014, Institut für Arbeitsrecht und Arbeitsbeziehungen in der Europäischen Union, Trier.

Clark, A.E. and Oswald, A.J. (1994) Unhappiness and unemployment, Economic Journal, 104, 648-59.

Clark, A.E., Georgellis, Y., and Sanfey, P. (1998) Job satisfaction, wage changes, and quits: evidence from Germany, Research in Labor Economics, 17, 95-121.

Clark, A.E. and Postel-Vinay, F. (2009) Job security and job protection, Oxford Economic Papers, 61, 207-39.

Council of the EU. (2008) Council Decision of 15 July 2008 on Guidelines for the Employment Policies of the Member States, Official Journal of the European Union, 2008/618/EC, Brussels.

Däubler, W. (2011) TzBfG-Teilzeit-und Befristungsgesetz, in M. Kittner, W. Däubler and B. Zwanziger (eds) Kündigungsschutzrecht, Bund, Frankfurt.

Deci, E.L. and Ryan, R.M. (2000) The 'what' and 'why' of goal pursuits: human needs and the self-determination of behavior, Psychological Inquiry, 11, 227-68.

De Cuyper, N., de Jong, J., de Witte, H., Isaksson, K., Rigotti, T., and Schalk, R. (2008) Literature review of theory and research on the psychological impact of temporary employment: towards a conceptual model, International Journal of Management Reviews, 10, 25-51. 
De Cuyper, N., Notelaers, G. and De Witte, H. (2009) Job insecurity and employability in fixedterm contractors, agency workers, and permanent workers: associations with job satisfaction and affective organizational commitment, Journal of Occupational Health Psychology, 14, 193-205.

De Graaf-Zijl, M. (2012) Job satisfaction and contingent employment, De Economist, 160, 197-218.

De Graaf-Zijl, M., van den Berg, G.J., and Heyma, A. (2011) Stepping stones for the unemployed: the effect of temporary jobs on the duration until (regular) work, Journal of Population Economics, 24, 107-39.

Ellingson, J.E., Gruys, M.L., and Sackett, P.R. (1998) Factors related to the satisfaction and performance of temporary employees, Journal of Applied Psychology, 83, 913-21.

Engellandt, A. and Riphahn, R.T. (2005) Temporary contracts and employee effort, Labour Economics, 12, 281-99.

Feldman, D.C., Doerpinghaus, H.I. and Turnley, W.H. (1995) Employee reactions to temporary jobs, Journal of Managerial Issues, 7, 127-41.

Ferrer-i-Carbonell, A. and Frijters, P. (2004) How important is methodology for the estimates of the determinants of happiness?, Economic Journal, 114, 641-59.

Frijters, P., Johnston, D.W., and Shields, M.A. (2014) Does childhood predict adult life satisfaction? Evidence from British cohort surveys, Economic Journal, 124, F688-F719.

Gallagher, D.G. and McLean Parks, J. (2001) I pledge thee my troth . . . contingently: commitment and the contingent work relationship, Human Resource Management Review, 11, 181-208.

Geishecker, I. (2012) Simultaneity bias in the analysis of perceived job insecurity and subjective well-being?, Economics Letters, 116, 319-21.

Gerlach, K. and Stephan, G. (1996) A paper on unhappiness and unemployment in Germany, Economics Letters, 52, 325-30.

Green, C.P., Kler, P. and Leeves, G. (2010) Flexible contract workers in inferior jobs: reappraising the evidence, British Journal of Industrial Relations, 48, 605-29.

Green, C.P. and Heywood, J.S. (2011) Flexible contracts and subjective well-being, Economic Inquiry, 49, 716-29.

Green, F. (2011) Unpacking the misery multiplier: how employability modifies the impacts of unemployment and job insecurity on life satisfaction and mental health, Journal of Health Economics, 30, 265-76.

Green, F., Felstead, A., and Burchell, B. (2000) Job insecurity and the difficulty of regaining employment: an empirical study of unemployment expectations, Oxford Bulletin of Economics and Statistics, 62, 855-83.

Jahn, E.J., Riphahn, R.T., and Schnabel, C. (2012) Flexible forms of employment: boon or bane, Economic Journal, 122, F115-24.

Judge, T.A., Heller, D., and Mount, M.K. (2002) Five-factor model of personality and job satisfaction: a meta-analysis, Journal of Applied Psychology, 87, 530-41.

Knabe, A. and Rätzel, S. (2010) Better an insecure job than no job at all? Unemployment, job insecurity and subjective well-being, Economics Bulletin, 30, 2486-94.

Knabe, A. and Rätzel, S. (2011) Scarring or scaring? the psychological impact of past unemployment and future unemployment risk, Economica, 78, 283-93.

Layard, R., Clark, A.E., Cornaglia, F., Powdthavee N., and Vernoit, J. (2014) What predicts a successful life? A life-course model of well-being, Economic Journal, 124, F720-F38.

Lüchinger, S., Meier, S. and Stutzer, A. (2010) Why does unemployment hurt the employed? Evidence from the life satisfaction gap between the public and the private sector, Journal of Human Resources, 45, 998-1045.

Lucas, R.E. and Donnellan, M.B. (2011) Personality development across the life span: longitudinal analyses with a national sample from Germany, Journal of Personality and Social Psychology, 101, 847-61.

McCrae, R.R. and Costa, P.T. Jr. (1987) Validation of the five-factor model of personality across instruments and observers, Journal of Personality and Social Psychology, 52, 81-90. 
OECD. (2004) OECD Employment Outlook 2004, OECD Publishing, Paris.

OECD. (2011) OECD Employment Outlook 2011, OECD Publishing, Paris.

Ochsen, C. and Welsch, H. (2012) Who benefits from labor market institutions? Evidence from surveys of life satisfaction, Journal of Economic Psychology, 33, 112-24.

Origo, F. and Pagani, L. (2009) Flexicurity and job satisfaction in Europe: the importance of perceived and actual job stability for well-being at work, Labour Economics, 16, 547-55.

Pouliakas, K. and Theodossiou, I. (2010) Measuring the utility cost of temporary employment contracts before adaptation: a conjoint analysis approach, Economica, 77, 688-709.

Rätzel, S. (2012) Labour supply, life satisfaction, and the (dis)utility of work, Scandinavian Journal of Economics, 114, 1160-81.

Specht, J., Egloff, B., and Schmukle, S.C. (2011) Stability and change of personality across the life course: the impact of age and major life events on mean-level and rank-order stability of the big five, Journal of Personality and Social Psychology, 101, 862-82.

Sverke, M., Hellgren, J., and Näswall, K. (2002) No security: a meta-analysis and review of job insecurity and its consequences, Journal of Occupational Health Psychology, 7, 242-64.

Theodossiou, I. and Zangelidis, A. (2009) Career prospects and tenure-job satisfaction profiles: evidence from panel data, Journal of Socio-Economics, 38, 648-57.

TzBfG. (2011) Teilzeit- und Befristungsgesetz, version of 20/12/2011, available at http://www. gesetze-im-internet.de/tzbfg (last accessed 29 June 2015).

Uysal, S.D. and Pohlmeier, W. (2011) Unemployment duration and personality, Journal of Economic Psychology, 32, 980-92.

Van Vliet, O. and Nijboer, H. (2012) Flexicurity in the European Union: flexibility for outsiders, security for insiders, Department of Economics Research Memorandum 2/2012, Leiden University.

Viinikainen, J., and Kokko, K. (2012) Personality traits and unemployment: evidence from longitudinal data, Journal of Economic Psychology, 33, 1204-22.

Wagner, G.G., Frick, J.R., and Schupp, J. (2007) The German Socio-Economic Panel Study (SOEP)—scope, evolution and enhancements, Schmollers Jahrbuch (Journal of Applied Social Science Studies), 127, 139-69.

Winkelmann, L. and Winkelmann, R. (1998) Why are the unemployed so unhappy? Evidence from panel data, Economica, 65, 1-15.

Wooden, M. and Warren, C. (2004) Non-standard employment and job satisfaction: evidence from the HILDA survey, Journal of Industrial Relations, 46, 275-97. 